\title{
A CONCEPTUAL STUDY ON CAR-SHARING SERVICES BASED ON SHARING ECONOMY1
}

\author{
Mustafa ALARÇİN 2 \\ İbrahim KIRÇOVA ${ }^{3}$
}

Received Date (Başvuru Tarihi):

$10 / 11 / 2020$

\author{
Accepted Date (Kabul Tarihi): \\ Published Date (Yayın Tarihi):
}

$15 / 12 / 2020$

$25 / 12 / 2020$

In the article, the first author is in the role of the Corresponding Author.

\begin{abstract}
Sharing is indicated as an alternative form of distribution to the exchange of goods and giftgiving. It encourages a sense of community, saves resources and creates specific synergies. Many factors

Keywords:

Sharing Economy,

Shared Mobility,

Car-Sharing

JEL Codes:

M15, M30, M31
\end{abstract}

\section{PAYLAŞIM EKONOMISİNE DAYALI OTOMOBİL PAYLAŞIM HİZMETLERİ ÜZERINE KAVRAMSAL BİR ÇALIŞMA}

$\ddot{O Z Z}$

\section{Anahtar Kelimeler: \\ Paylaşım Ekonomisi, \\ Paylaşımlı Ulaşım, \\ Otomobil Paylaşımı}

JEL Kodlar:

M15, M30, M31
Paylaşım, malların değişimi ve hediye verme için alternatif bir dağıtım şekli olarak ifade edilmektedir. Alternatif türleri ile karşılaştırıldığında, paylaşım topluluğu teşvik edebilmekte, kaynakları kurtarabilmekte ve belirli sinerjiler yaratabilmektedir. Internet hizmetlerinin ve akıll telefonlarm kullanımının artması, küreselleşme ve kentleşme, e-ticaret hacminin artması, çevrimiçi ödemelere olan güvenin artmasl, küresel ekonomik kriz, genel tutumlardaki değişimler ve tüketimde sürdürülebilirliğe daha fazla dikkat edilmesi gibi birçok faktör, son yıllarda paylaşım ekonomisinin gelişmesine yol açmıştır. Paylaşım ekonomisi, insanlara kaynaklar verimli kullanma ve boşta bekledikleri zamanlarda en çok ihtiyaç duyulan yerlere dă̆ıtma imkânı sağlamaktadır. Paylaşım ekonomisinin önemli alanlarından birisi olan paylaşımlı ulaşım şehirleşmenin artması, sahiplik maliyetlerinin yükselmesi ve tüketim alışkanlıklarının değişmesinden ötürü hızla büyümektedir. Paylaşımlı ulaşım hizmetlerinin farkl türleri olsa da, Türkiye'de en yaygın olanı otomobil paylaşım hizmetleridir. Paylaşım ekonomisine dayalı otomobil paylaşım hizmetlerine yönelik yapılan bu kavramsal çalışmada derinlemesine literatür incelemesi yapılmıştır. Bu bağlamda ilk olarak paylaşım ekonomisi kavramı ve önemi üzerinde durulmakta, sonrasında paylaşımlı ulaşım türleri ayrı ayr ele alınmaktadır. Son olarak otomobil paylaşım hizmetleri ve türleri incelenmektedir. Bu çalışma ile paylaşım ekonomisi literatürüne otomobil paylaşım hizmetleri konusunda kapsamlı bir katkı sağlanması amaçlanmaktadır.

\footnotetext{
${ }^{1} \mathrm{Bu}$ çalışma Prof. Dr. İbrahim Kırçova danışmanlığında yürütülen ve Mustafa Alarçin tarafından yazılan doktora tezinden derlenmiştir.

${ }^{2}$ Doktora Öğrencisi, Yıldız Teknik Ünv., Sosyal Bilimler Ens., m.alarcin@hotmail.com, https://orcid.org/0000-0002-6484-6131

${ }_{3}^{3}$ Prof. Dr., Yıldız Teknik Ünv., İ.̇̇.B.F İşletme Bölümü, ibrahimkircova@gmail.com, $\underline{\text { https://orcid.org/0000-0003-2381-5459 }}$
} 


\section{INTRODUCTION}

The idea of sharing and using things together is not new, but a phenomenon as old as humanity. However, the dimension of sharing physical products has been relatively limited in the past due to both the difficulty in matching supply and demand and the lack of trust between the lender and the borrower. In recent years, the rise of digitalization has filled these gaps. Today, an increasing number of companies are enabling the use of digital platforms that ensure easy matching of demand and supply and the necessary trust between users. In this way, even materialistic consumers who are more inclined to own something can benefit from the sharing economy (Ranjbari et al., 2018: 1). In sharing, two or more people can take advantage of the gains or costs that result from owning something. Rather than separating something as "mine" or "yours"; it is defined as "ours". Thus, apart from sharing a house, car or any other tangible products needed, intangible things such as knowledge, responsibility, and power can also be shared (Belk, 2007: 126-127; Belk, 2010: 715). Sharing is "the universal form of humane economic behaviour" (Altinay and Taheri, 2018: 180).

Sharing economy refers to the exchange structure facilitated by the use of online platforms and includes a variety of activities aiming broadly to access underused resources through the method called "sharing" (Pappas, 2016: 2303). Studies generally express the concept of sharing economy as the sharing access to underused goods and services interpersonally, which prioritizes use and accessibility over ownership (Kim et al., 2018: 110). The sharing economy differs from traditional business models with its high dependency on the internet platform, lack of ownership of goods and services, access to idle resources, providing more customized products and services at lower prices, and innovative workforce (Mao and Lyu, 2017: 2464). In short, sharing economy changes resource allocation, business models and consumer behaviours in many sectors, including tourism and accommodation and transportation (Zhu et al., 2018: 2219).

The sharing economy offers environmental, economic and social benefits to all stakeholders, including consumers, service providers and application provider companies (Buczynski, 2013: 18; Altinay and Taheri, 2019: 182). Sustainable 
developments are an essential issue in today's economy due to the depletion of natural resources. Sharing economy, on the other hand, is seen as an essential way for people to have a more sustainable and low-carbon lifestyle. The sharing economy also supports different sustainable transportation methods such as bicycle, car and ridesharing based on temporary access rights, not ownership that will increase high investment costs for key stakeholders of society such as people, municipalities and states. In this context, as a result of the increase in the use of sharing economy services, of which more sustainable vehicles are a part, the car ownership, gas emission and transportation costs decrease with the increase in the use of shared public vehicles (Liu, Yang, 2018: 1-3). In summary, sharing economy has gained importance and interest primarily due to the participation of individuals to the sharing economy communities and the fact that the benefits provided to the other people and environment by sharing the provided services, helping others and engaging in sustainable behaviour (Hamari et al., 2015: 2048).

In the last decade, car-sharing services have become more attractive to consumers and become a worldwide industry. Car-sharing service is defined as the service through which members of shared-use car organizations access a car fleet. Carsharing services reduce the number of cars in traffic and contribute positively to the environment (Hartl et al., 2018: 89-90). The need for sustainable transportation services has increased enormously due to the continuous increase in the population and the settlements in cities, the problem of parking spaces and the rapid increase of urbanization. On this basis, it is observed that each shared cars remove 9 to 13 personally owned cars from the traffic, thanks to the use of car-sharing services offered by companies (Cohen and Kietzmann, 2014: 281-288; Katzev, 2003, 69). Therefore, this research examines the factors that affect consumers' intention to use car-sharing services based on the sharing economy.

\section{LITERATURE REVIEW}

\subsection{Sharing Economy}

In recent years, attitudes towards consumption have changed and brought concerns about ecological, social and developmental impact. The growing concern 
about climate change and the longing for social interaction by people have made the "sharing economy" an attractive alternative for consumers. Information and communication technologies, which are developing rapidly, especially with web 2.0, have enabled the emergence of the concept called "sharing economy". The concept of sharing economy can be expressed as the activity of acquiring the right to access goods and services, giving each other or sharing, coordinated through online services based on the community between individuals (Hamari et al., 2015: 2047; Choi et al., 2014: 625). The sharing economy is defined as the traditional sharing, bartering, lending, trading, leasing, gift-giving and exchanging activities that are redefined through technology and communities of like-minded people and that reshape our business, consumption and lifestyle (Botsman and Rogers, 2010: 7; Nwaorgu, 2018: 240; Liu and Yang, 2018: 3; Belk, 2014: 1597).

According to studies, the sharing economy is expected to alleviate social problems such as overconsumption, air pollution and poverty by reducing the cost of economic coordination within communities (Hamari et al., 2015: 2047). Eckhardt et al. (2019: 7) defines the concept of sharing economy as a measurable socio-economic system that uses technology-supported platforms to provide users with temporary access to intangible and tangible resources. The sharing economy is expressed in many structures such as online and digital platforms, activities, resources, exchange structures, an economic model, systems, a socio-economic model, an ecosystem, companies, types of business models, different economic activities, a market, an economic and ecological phenomenon, value, entrepreneurship from start to finish, cooperation between private, public, and community (Ranjbari et al., 2018: 2).

From the marketing point of view, companies that offer services by the traditional business model aim at brand relationships centring on keeping the experiences of consumers under control. On the other hand, companies that offer sharing services such as car-sharing do not know whether they should focus on the relationship with the company providing the service, or the company providing the platform service, or else the person sharing it, as the brand relationship is shaped during the use of the service (Eckhardt et al., 2019: 13-19). In the sharing economy business model, it is crucial to provide data, a privacy-focused platform, and a trust- 
oriented service. The most critical tasks of companies that provide services in the field of sharing economy are to offer innovative business models, create reputable brands and act as a trusted provider (Chen and Wang, 2019: 20).

The essential feature that distinguishes the sharing economy from traditional business models is that it offers services based on access rather than ownership. In other words, traditional companies focus on giving ownership rights to their consumers and producing products and services that people will buy. However, companies that provide services in the field of sharing economy offer temporary access to their products and services instead of permanent ownership. Also, although consumption sharing and access to resources have long been offered under traditional rental services, the sharing economy is built on the digital economy that allows data to exchange and create value in an unprecedented way. From a marketing perspective, the sharing economy offers the best service by matching customers and suppliers in order to improve the customer experience, as well as providing companies with value throughout the entire value chain and the opportunity to create value for customers through innovation. In the future, marketing should consider the sharing economy as an essential type of the digital economy. With the data obtained within the scope of sharing economy, it can be determined how to create value for different stakeholders such as consumers, society and companies. Finally, marketing studies need to reveal the challenges and expectations for business models from the perspective of both developing and developed markets (Eckhardt et al., 2019: 13-19; Chen and Wang, 2019: 28-30).

According to the study named "Sharing Economy: The Growth of the Sharing Economy" conducted by $\mathrm{PwC}$ in 2015, companies that generate 15 billion dollars of revenue in five primary sectors of the sharing economy in 2013 are expected to generate 335 billion dollars revenue by 2025 as shown in Figure 1. The five primary sectors of the sharing economy are classified as crowdfunding, on-demand employment, accommodation services based on sharing economy, on-demand streaming services and car-sharing services. In this context, it is thought that companies operating in the field of sharing economy will receive half of the total income from companies operating with traditional business models (PWC, 2015a). 
According to the study conducted by Statista, it is estimated that the participation in the sharing economy in the USA in 2021 will be more than the total population of Germany with 86.5 million people (Statista, 2020). According to the research of Schroders, the compound annual growth rate of the use of car-sharing services in the world is expected to be $23 \%$ by 2025 (Schroders, 2016). According to the research conducted by Deloitte, 43\% of the consumers living in China in 2016 stated that they preferred car-sharing services at least once a week. Generally, it is observed that the consumers living in the city of traffic congestion, parking problem and costs (Deloitte, 2017). According to the research of PwC, BlaBlaCar, an essential player of car-sharing services, has more than 20 million users in 19 countries, and Zipcar, the world's largest on-demand car-sharing service provider, has more than 1 million users on a global scale (PWC, 2015a).

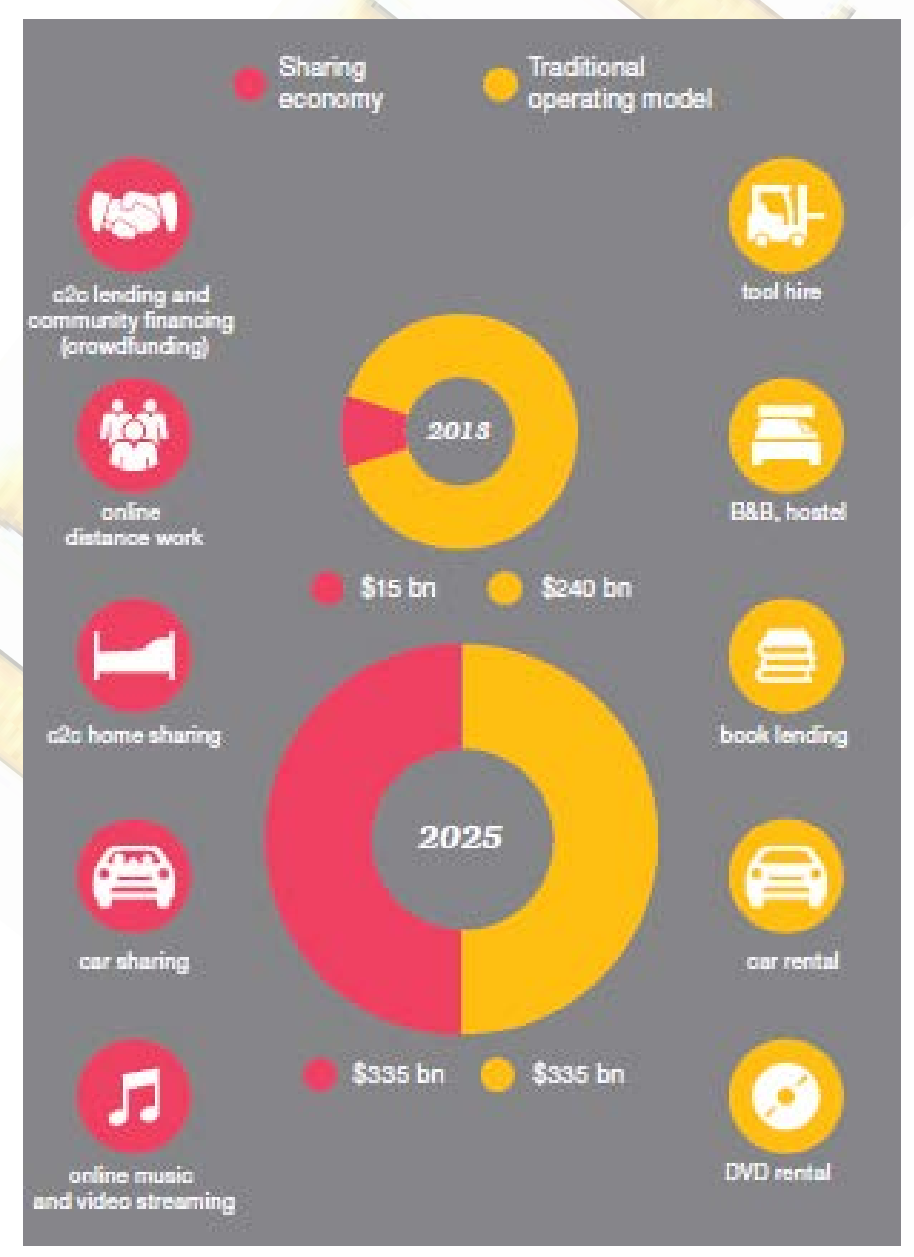

Figure 1. Growth Forecast of Sharing Economy 
Another study conducted by PWC, named as "Sharing Economy-Customer Intelligence Series", shows that sharing economy services provide economic gain for consumers, make their lives more efficient and productive, contribute to the environment, create healthy communities for consumers. That interaction with companies and other people offers entertainment and trust is at the forefront (PWC, 2015b). In Turkey, according to the report issued by ING, the reasons for the consumers to participate in the sharing economy are founded as saving, gaining economic gain, solidarity and contributing to the environment. The study also refers to the element of trust as the reasons for avoiding sharing (ING, 2015). It is stated that the estimated sharing economy market in Turkey in 2017 was 38.3 billion dollars, and car-sharing services represented more than $10 \%$ of this. It is also stated that Turkish consumers find car-sharing services more reliable than traditional providers. Table 1 shows the critical indicators for the sharing economy activities in Turkey (PWC, 2017).

Table 1. Sharing Economy Activities in Turkey

\begin{tabular}{|c|c|c|}
\hline \multicolumn{3}{|c|}{ Most Used Sharing Economy Activities } \\
\hline Media and Entertainment & Retail and Consumer Goods & $\begin{array}{l}\text { Automotive and } \\
\text { Transportation }\end{array}$ \\
\hline Spending in Sharing Economy & Gender (mostly used by) & Profile(mostly used by) \\
\hline $1.031 €$ on average & Female & $\begin{array}{c}\text { A highly educated person between } 18 \\
\text { and } 39\end{array}$ \\
\hline \multicolumn{3}{|c|}{ Advantages } \\
\hline Better price for performance & More value for users & Flexibility to choose different options \\
\hline
\end{tabular}

Note: The information in the table is aggregated from the respective research. Source: PWC, 2017.

There are more than 2000 shared cars in the car-sharing services sector, which includes essential competitors such as MOOV by Garenta, DriveYoYo and Zipcar in Turkey, and it is aimed to exceed 3500 shared cars. In the study conducted by the MOOV by Garenta in order to measure the usage habits of consumers after the Covid19 outbreak, it was revealed that car-sharing services would be used more after the pandemic. Again, according to the results shared by the company, it is stated that the demand for car-sharing services increased by $18 \%$ during the pandemic, and there 
were more than 400 thousand users in total with more than 30 thousand new participants in March, April and May 2020 (Webrazzi, 2020).

\subsection{Mobility Services Based on Sharing Economy}

Sharing economy is a socio-economic system that enables individuals who are in contact with each other to exchange unused or excess resources with each other in return for a price or different benefits (Tussyadiah and Zach, 2017: 636). It is stated that there are five main types of sharing economy where unused resources or excess resources are redistributed through companies such as Airbnb, Uber, Zipcar, BlaBlaCar, Kickstarter, TaskRabbit, Netflix (PwC, 2017). These are crowdfunding, ondemand employment, accommodation services based on sharing economy, ondemand streaming services and mobility services based on sharing economy. Mobility services based on sharing economy is an essential type of sharing economy and the best example of the effect of sharing economy on traditional industry. Shared mobility services offer a sustainable, affordable, safe and convenient alternative to traditional transportation services (Cohen and Kietzmann, 2014: 283-284).

Car-sharing refers to the mobility services in which members have the right to access the car fleet of a particular company for a fee over a specific time. This carsharing service is a popular alternative to car ownership, demonstrating the transition from individual ownership to this new sharing economy in the cultures of developed countries. Ridesharing, another vital type of shared mobility refers to the services in which a person shares the trip in a vehicle that is going to a specific place by paying the fee. Ride-hailing services offered through the internet-based mobile application, which is expressed as a combination of car and ride-sharing services, refers to sharing services that do not have a commercial license, but that enables the driver to profit (Posen, 2016: 413-414). The fundamental reasons for the growth of car-sharing services day by day are the more effective and efficient provision of the service on the mobile application, the increase in the number of shared cars and the faster response to the needs, the inadequacy of public transportation and taxi services, and the competitive price (Cramer and Krueger, 2016: 3). 


\subsubsection{Shared Mobility Services Types}

Public perception of shared products and services has changed significantly in recent years. Recent developments in the sharing economy and information technologies have created new business areas, changed how people plan and make their travels, and expanded ownership and transportation models. Shared mobility has been an important growing area of the sharing economy. Shared mobility points to shared transportation services among users, where route planning is the central issue (Tong et al., 2018: 1633). The increasing expansion of cities day by day and the resulting population growth is a crucial pressure factor for the reliability of transportation systems. Transportation forms the basis of economic well-being and quality of life in cities. For this reason, public institutions have been closely following the development of shared mobility services since the emergence and applying them in the form of direct investment or partnership in the area of transportation services (Iacobucci et al., 2017: 65). Shared mobility, shared use of bicycles, cars and other vehicles is an innovative mobility strategy in which consumers gain short-term access to different types of transportation as they need (Shaheen et al., 2017a: 1).

There are different types of shared mobility such as bike-sharing, scooter sharing, on-demand ride-sharing and car-sharing. Smartphones and mobile applications are essential to optimize the service and ensure its operation for shared mobility types. Wherever the application areas of shared mobility are increasing, the effects such as decreasing costs, being easily accessible, shortening the distance travelled by cars, reducing individual car ownership and gas emissions are observed (Shaheen et al., 2015: 3; Feigon and Murphy, 2016: 7). Especially in big cities struggling with increasing density and population growth, it is aimed to reduce problems such as air pollution, lack of transportation and traffic congestion with mobility services based on sharing economies such as bicycle, scooter, on-demand ride-sharing and carsharing. The fact that people use their vehicles to get where they want to go as quickly as possible increases the number of vehicles in traffic and requires maintenance for more car parking areas and roads. In addition to these, individual automobile use can cause health problems because it causes more air pollution and minimizes the movement of people (Schechtner and Hanson, 2017: 77; Cohen and Kietzmann, 2014: 
279-281). Demographic changes, economic issues, environmental concerns and lifestyles have taken transportation needs to a different level. People now want to stay away from the noise made by car, exhaust smoke, and traffic jams in city centres. For this reason, people support the need for a smart city of which shared mobility is also part of increasing their quality of life (Aguilera-Garcia et al., 2019: 1).

\subsubsection{Bike Sharing}

Bike-sharing has emerged as the fastest-growing innovative mode of transportation in many major cities. Since it does not require the use of any energy, it serves as the most effective and efficient mode of transportation and has a significant impact on public transportation. Bike-sharing is a sharing service that provides access to bicycles at stations located at specific points of the city on an hourly basis, usually as one-way ride. In this way, it eliminates the necessity of buying bicycles for people and meets their needs (Feigon and Murphy, 2016: 5; Liu and Yang, 2018: 2; Campbell, 2016: 406). While some bike-sharing service providers provide their users with service between an individual station network, some allow free movement within a particular area. Many bike-sharing programs charge membership fees as well as usage fees. Providers mostly cover maintenance, storage and parking costs themselves (Shaheen et al., 2017a: 6). The benefits of bike-sharing can be expressed as increased mobility, reduced costs, lower operating costs, less traffic congestion, reduction in fuel consumption, increased use of other public transport modes, healthy living, environmental awareness and economic development (Shaheen et al., 2016: 25; Wielinski et al., 2017: 113; Fishman et al., 2013: 150; Wang and Zhou, 2017: 148).

\subsubsection{Scooter Sharing}

Transportation is one of the most basic human needs today. It helps us take advantage of the many opportunities offered in life. An essential mode of shared mobility that can be shown as an alternative to cars without making significant restrictions in people's lives is scooter sharing (Hardt and Bogenberger, 2019: 155). Scooter sharing is today's variation of the car-sharing business model. As with carsharing services, both free-floating and round-trip based scooter sharing services are offered. Scooter sharing is a sharing service that is positioned unlocked at appropriate 
points in the central places where the population is concentrated, especially in big cities, activated by reading a QR code on the mobile application and charged throughout use (McKenzie, 2020: 1-2; Shaheen et al., 2017a: 6). Scooter sharing service providers pay a fee to their users if they charge the scooters at their home through the crowdsourcing program they have created. Besides, company employees support to redistribute scooters so that they do not accumulate in a single point (McKenzie, 2019: 22). The most crucial problem solved by scooter sharing can be expressed as meeting the need for distances that are too short to go by car and long to walk (Allem and Majmundar, 2019: 62). Studies show that the scooter sharing service is preferred near city centres, university districts, resting places, open areas and public transportation stations. It is also observed that generally well-educated and young population prefer scooter sharing services (Bai and Jiao, 2020: 271; Shaheen and Cohen, 2019: 8-9).

\subsubsection{On-Demand Ride Sharing}

On-demand ride-sharing refers to two primary services, namely, carpooling and peer-to-peer ride-sharing services. Carpooling is the services where the vehicle owner shares the same ride by matching with other passengers who want to go from a certain point of departure to the same arrival point through an application. BlaBlaCar, TwoGo and SeatX are the service providers within this context. The purpose of using carpooling services is to reduce the number of individual vehicles in traffic, use of gasoline and air pollution, and to increase efficiency in urban transportation systems by sharing the cost of the car owner, beyond making a profit (Shaheen et al., 2017b: 181; Agatz et al., 2012: 295). Another type of on-demand ridesharing is the peer-to-peer ride-sharing services. Peer-to-peer ride-sharing services are the sharing service in which a person accesses the ride service offered by a driver, who registered to the platform with his car, at the request of a mobile application for a specific fee (Henao and Marshall, 2017: 200). Uber that also provided services in Turkey for a short time is an important example of this service type. Peer-to-peer ridesharing services are an additional source of income for drivers, as well as a valuable type of service for people to make a social network. Besides, it has a more affordable and faster response compared to traditional taxis. Thus, it can be said that it competes with traditional taxi services the most (Jin et al., 2018: 98; Albinsson and Perera, 2018: 
103). Three key elements are at the centre of the success of peer-to-peer ride-sharing service providers like Uber. The first is that it increases efficiency with access to new cars; the second is that it provides transparent services with technological developments, and the last is that traditional taxi services have a negative impression (Schneider, 2017: 37). Since the basis of this study focuses on car-sharing services, it will be discussed under the main heading below.

\subsection{Car-Sharing}

Car-sharing services are turnkey services where the consumer pays a fee over distance or time and is not responsible for expenses such as insurance, gasoline, maintenance. Car-sharing services are generally preferred for short trips, require being a member of a platform, and provide access to the cars offered by this platform. In Turkey, companies such as MOOV by Garenta, Zipcar and driveYoYo are providing mobility services in this context. Service provider companies locate their cars in specific points of the city so that their consumers can easily access to their fleet and provide vehicles to stations with their employees when necessary to provide uninterrupted service. Car-sharing services not only support the aim of sustainable transportation but also aim to provide profitability. Through the application, customers can see where the closest car is, access the car with a membership card and drive for the time or distance they need. Thus, idle time because of not driving the car is reduced, and the cost and benefit are balanced. Car-sharing services reduce the number of cars in traffic and air pollution. Rather than owning a car, people can access cars whenever they need without the cost of maintenance and ownership. (Cohen and Kietzmann, 2014: 283-284; Yun et al., 2020: 2). Some car-sharing business models are shown in Table 2. car-sharing services reduce the use of public transport and encourage people to use alternative modes of mobility, such as walking and bicycle rides. Car-sharing services are successful because they offer both a more convenient and better mobility services for consumers (Shaheen et al., 2015: 6-7). car-sharing services differ from the traditional full-day rental services, as they are charged over time and distance, they are used, and they require short-term use. Finally, consumers must complete time-consuming transactions such as signing many documents each 
time in traditional rental services, while they can complete the process with a one-time membership transaction in car-sharing services (Katzev, 2003: 67-68).

\subsubsection{Car-Sharing Types}

Car-sharing is changing the automotive industry. Access-based car-sharing services are transforming the current business model of the automotive industry, although it has not yet fully established itself (Wilhelms et al., 2017a: 105). While carsharing reduces the adverse effects of individually owned cars, it appears as a flexible service that meets the different transportation needs globally. Car ownership has been losing its importance in recent years. Crowded streets, lack of parking spaces, and rising costs have made people rethink car ownership and use and look for new alternatives. Car-sharing is seen as the most important alternative to car ownership in this sense (Bardhi and Eckhardt, 2012: 886; Yau and Mahn, 2015: 746). The most crucial principle of car-sharing is that consumers get rid of the liabilities and costs arising from car ownership and access shared cars by paying only usage or membership fees. Individually owned cars spend $95 \%$ of their time waiting idle, so car-sharing allows efficient use of cars (Shaheen et al., 2015: 6; Shaheen et al., 2017a: 3). In the past, people attached importance to cars with their own identities and saw them as a symbol of prestige, but today mostly the young and educated population see it as a means of transportation (Paundra et al., 2017: 123).

For this reason, people prefer sharing services, which are a business model that will meet their needs with more affordable costs, rather than owning them. People with a similar mindset with sharing economy communities come together and become members of a different community apart from their group of friends and family (Millard-Ball et al., 2005: 3-8; Klincevicius et al., 2014: 49). In summary, consumers adopt a more sharing-oriented life philosophy and move away from the concept of ownership by experimenting with different types of car-sharing services (Kim et al., 2019: 124). In this study, car-sharing is classified as peer-to-peer car-sharing, roundtrip car-sharing and free-floating car-sharing (Jochem et al., 2020: 374). 


\subsubsection{Peer-to-Peer Car-Sharing}

Peer-to-peer car-sharing is sharing services that bring together individuals who want to share their cars for a short time using the web or mobile technologies with potential drivers (Feigon and Murphy, 2016: 5; Hampshire and Gaites, 2011: 119). In peer-to-peer car-sharing services, people have the roles of both consumers and service providers. This type of car-sharing encourages people to share the car they own with others. Especially with the increase of digital technologies, car-sharing services are provided more professionally and reach more people (Münzel et al., 2019: 278). Also, it offers the car owner the opportunity to earn additional income during the period of non-use. The companies providing this type of service provide only infrastructure support services such as a suitable platform, customer support and insurance to ensure that the transaction between the car owner and the person accessing the service is carried out smoothly. Members of the platform can access cars either directly through the key taken from the car owner or through vehicle technologies integrated by the service provider (Cohen and Kietzmann, 2014: 284-286; Shaheen et al., 2017a: 5; Shaheen et al., 2015: 8-9). Since people who want to make a profit in peer-to-peer carsharing services share the cars, the companies providing the service do not have an automobile fleet. For this reason, since intermediary firms do not have high costs, they only receive membership fees that will cover their operational costs (Wilhelms et al., 2017b: 38). The most important feature that distinguishes between peer-to-peer carsharing from on-demand ride-sharing is that the car owners give their cars to the people who request it through the platform for temporary use. Users pay a specific fee for each time they get the car. Peer-to-peer car-sharing services are generally shared programs operated and supported by environmentalist communities in the area they are in (Buczynski, 2013: 131-132). Obstacles to the more use of peer-to-peer car-sharing are expressed as insurance costs, not being easily accessible everywhere, fear of damaging the car, fear of sharing, lack of trust, pricing problems, technology costs and the quality of cars (Ballus-Armet et al., 2014: 28). 


\subsubsection{Round-Trip Based Car-Sharing}

Round-trip based car-sharing refers to sharing services where cars are available at the stations of the service provider and left back to the point where they are mostly taken (Feigon and Murphy, 2016: 5; Cohen and Kietzmann, 2014: 283-284). The most important effects of this type of car-sharing are reducing the number of cars in traffic, gas emissions, need for parking and individual car ownership. A significant number of people who benefit from round-trip based car-sharing services either postpone their individual car purchasing decisions or sell the car they own. In this context, it is stated that a car serving in this type of car-sharing reduces between nine and thirteen individual cars from traffic as shown in Figure 2 (Ciari and Becker, 2017: 53; Shaheen et al., 2017a: 3-4).

\section{CARSHARING IMPACTS}

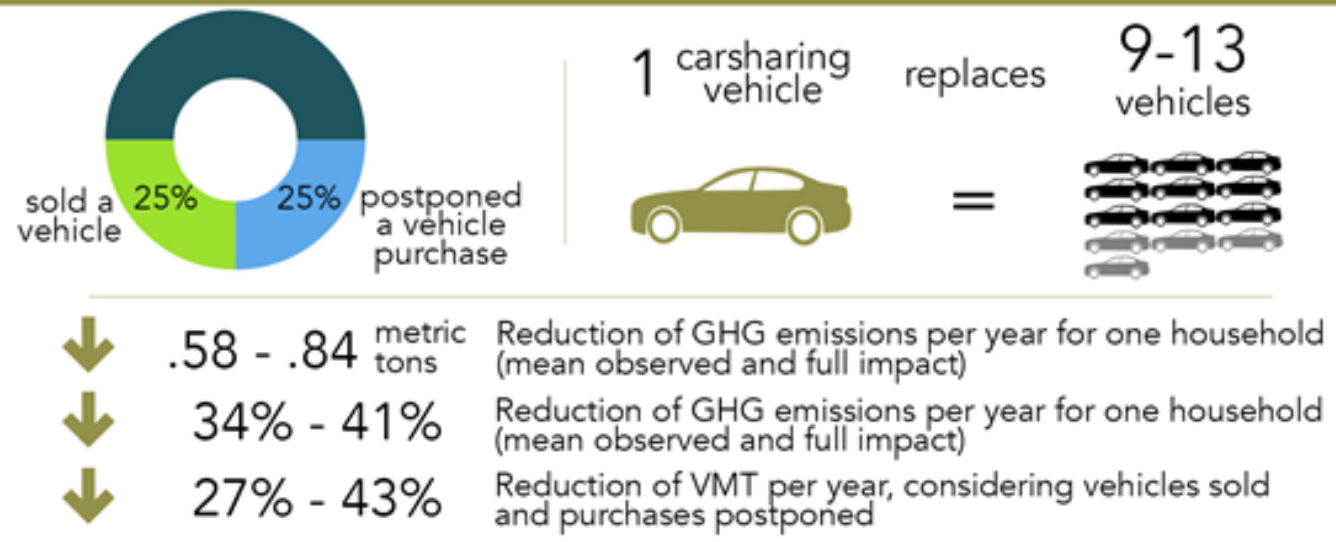

More carsharing users increased their overall public transit and non-motorized modal use (including bus, rail, walking, bicycling, and carpooling) than decreased it.

- For every 5 members that use rail less, 4 use it more.

- For every 10 members that ride the bus less, 9 ride more.

$\$ 154$ - \$435 Monthly household savings per US member after joining carsharing

Figure 2. Car-Sharing Impact

Source: Shaheen et al. 2017a: 4 .

The most important advantage, especially over free-floating car-sharing, is that as supply and demand management is carried out based on stations, members are much more likely to find a car when they need to drive. Also, it contributes to both shared mobility and traditional transportation and still encourages people to walk. Even if people use round-trip based car-sharing for short-term rides in the city, they 
benefit from public transportation facilities such as traditional taxi and rail transportation systems, both for door-to-door transportation and for short-distance trips, especially in cities where they stay or live for a long time (Jorge et al., 2015: 360; Kopp et al., 2015: 451-452). People who do not own a car prefer round-trip based carsharing more than free-floating car-sharing because they can travel for a longer time and position them temporarily instead of individual cars (Yoon et al., 2017: 111). Round-trip based car-sharing services are defined as the short-term accessible type of traditional car rental and are the first example of car-sharing services. Users who purchase a membership for the service pay a fee over the time and distance used, as well as a monthly or annual subscription fee (Shaheen et al., 2015: 6; Le Vine et al., 2014: 219).

\subsubsection{Free-Floating Car-Sharing}

Free-floating car-sharing refers to sharing services where people access cars parked at specific points of the city, park the car in a suitable place within the designated area at the end of the ride, and generally travel one-way (Feigon and Murphy, 2016: 5; Cohen and Kietzmann, 2014: 283-284; Shaheen et al., 2017a: 5). In this type of car-sharing, consumers use the cars of the service provider company they are a member of and pay a fee over this period (Akyelken et al., 2018: 2). The most important feature that distinguishes free-floating car-sharing from other car-sharing types is the flexibility to be taken from any desired point within the geographical area determined in large cities with high population and left to any desired point. It is an impressive sharing service as no prior reservation is required, and it does not have to be brought back to the point where it is taken. The location of the cars can be easily found via the application with the GPS feature (Ciari et al., 2014: 37; Firnkorn and Müller, 2015:31). In this type of sharing, the cars of the companies that provide services vary according to the development level of the countries and the dynamics of the market, but they are generally small and electric cars. In this way, it prevents parking problems in the cities where the service is provided, causes less gasoline consumption and reduces the damage to the environment (Firnkorn and Müller, 2011: 1525-1527). The most crucial feature of free-floating car-sharing compared to round-trip based carsharing is the more efficient use of cars. In the round trip-based car-sharing, the cars 
are used by the same person until they are brought back to the point where the cars were taken, and therefore they remain idle during the time they are not driven. However, the moment the car shared with free-floating car-sharing is left at the destination point, it is ready for the next consumer and thus the idle time is much less (Balac et al., 2017: 207). The biggest obstacle for the users of free-floating car-sharing is the inability to find a car whenever and wherever they want. For this, service providers pay attention to the distribution of cars within their service area and try to locate more cars in cities where the service is used a lot (Ciari et al., 2014: 18).

\section{DISCUSSIONS}

In Turkey, many different stakeholders such as companies, public institutions (e.g., municipalities), start-ups, and individuals both provide and benefit from the service in almost every field of the sharing economy. Sharing economy services are expected to have half of the online commerce volume in the coming years. Therefore, the importance of understanding the sharing economy phenomenon is increasing day by day for both researchers and practitioners. Although the studies within the sharing economy in Turkey are limited, they are mostly made in the field of tourism and accommodation services. There are a few studies on car-sharing services in Turkish literature. It is seen that researches conducted in the field of sharing economics generally measure satisfaction and re-use behaviour; nevertheless, the factors that affect intention and use were also indirectly investigated in some studies. Thus, it is expected that this study will make a significant contribution to the gap in the literature on car-sharing service based on sharing services. Especially in Turkey, where the companies offering car-sharing services are a few, it is expected that the study will make an important contribution to the market for the practitioners to conduct marketing activities. A comprehensive literature review is done in order to conduct this conceptual study. The researchers conducted in both developed countries where the car-sharing services are mostly used, and the developing countries, which are similar to Turkey have been reviewed in this regards. 
Sharing economy is an economic model that changes consumption habits and lifestyles. On the one hand, it provides access to products and services that are very costly to own for some, while it allows more efficient use of scarce resources for others. The sharing economy offers environmental, economic and social benefits to all stakeholders, including consumers, service providers and application provider companies. Sustainable developments are an essential matter in today's economy due to the depletion of natural resources. Sharing economy, on the other hand, is seen as an important way for people to have a more sustainable and low-carbon lifestyle. The sharing economy also supports different sustainable mobility modes such as cycling, car and ride-sharing based on temporary access, not ownership, which will increase high costs for key stakeholders of society such as people, municipalities and states. On the other hand, especially those who provide peer-to-peer sharing services both earn money and meet new people. Participation in the sharing economy offers people the opportunity to create a social environment. For example, when a user uses accommodation services on Airbnb or mobility services with Uber, BlaBlaCar, they can meet new people and socialize. However, if they stay in a hotel, they are more likely not to meet anyone during the period they stay there.

The transportation industry has been at the centre of exchange in recent years. Many companies, including public institutions and car producers, have started to offer shared mobility services such as carpooling, bike, scooter, ride and car-sharing, in order to reduce the air pollution, traffic and costs. In order to support sustainability, companies generally offer both small and electric cars; thereby, they reduce also the parking need in bigger cities. Research shows that most young and well-educated population use access-based car-sharing services rather than owning a car to avoid the high investment costs. Even though the products and services they use are different from the older generation, the expectation from the products and services in regards to shared mobility services are the same as low cost, comfort, flexibility and convenience.

While the car-sharing services are part of the daily transportation modes in developed countries like Germany, it is still experiencing the early stage in Turkey. Companies providing car-sharing services have increased their operation, especially 
in the last couple of years. Even though the certain factors have not been investigated deeply, some sector researches indicated that trust, consumption habits and costs are found as the primary reasons why people do not use the car-sharing services as part of daily transportation. People who are thinking of using the car-sharing services expresses that they have lower trust to the car-sharing companies because they believe the companies would charge them higher services costs and cost of the damage, they are not responsible. The costs seem to be higher for most of the consumers to re-use the service. The costs are primarily found if it is compared to the examples in the developed countries because the costs are meagre there to make the car-sharing as part of the daily routine in all types of car-sharing services. In Turkey, the prices of cars are high due to the exchange rate because most of the cars are exported from other countries; and the inflation rates increase the costs. Besides the higher investment costs, running costs such as maintenance, insurance and operation costs are also high depending on the overall economic situation in Turkey. However, despite all these, companies continue to make their investments and provide more accessibility at affordable prices possible.

Car-sharing services, which grow continuously, are moving towards becoming a part of daily life. Car-sharing services are perceived as easy and convenient by most of the users. Thus, people prefer the services in order to go to the offices, supermarket or home regularly and for mobility in the city centres. As the car-sharing services reduce the number cars on the road, traffic congestion and parking issues, it can clearly be stated that the business model positively contributes to the environment and society (Ciari et al., 2014, 38). A vital issue perceived by many people regarding sharing services is trust. Therefore, companies and service providers are recommended to plan their strategies that build a high perception of trust, mostly through word-of-mouth marketing activities (Ballus-Armet et al., 2014: 35). Another critical way to increase the perception of trust is to support the community understanding that people publicly comment and rate because people who intend to use the services can be affected by the others. It is proposed that municipalities, institutions and organizations develop multi-modal transportation methods, which include car-sharing services in order to reduce the time people spend in traffic and meet their transportation needs quickly. 
Studies show that it is generally essential for people to gain economic benefits and to access services easily (Münzel et al., 2019, 291). Therefore, it is recommended that service providers carry out advertisement campaigns showing the economic advantage of using car-sharing services against car ownership and plan supportive activities such as discounts and voucher for users to re-use the services. It should be emphasized that the shared car business model is environmentally promising for the society and the planet in order to increase a similar awareness among consumers to motivate them, significantly since the use of electric vehicles today is increasing and companies support sustainable modes of transportation within the context of sharing economy (Wilhelms et al., 2017a: 105). Researches indicate that the younger generation prefers car-sharing against ownership (Katzev, 2003, 81). Thus, campaigns should primarily be made to motivate young people because they give importance to less ownership and make up the majority of the population.

Studies conducted in recent months show that people prefer car-sharing services more because of the desire to stay away from public transportation due to the pandemic and the increased costs of car ownership in Turkey. As a result, it can be suggested as an essential strategy that public institutions and car manufacturers can provide a joint service to share the higher investment and operation costs and expand the service, especially in big cities in order to support the common goals of car-sharing in the globe. This study provides comprehensive background information about carsharing services based on sharing economy, but it is highly recommended to the future researchers to investigate the factors that affect the usage intention of car-sharing services in Turkey. In this way, researchers and practitioners will be able to plan the necessary marketing strategies within the framework of obtained factors. 


\section{REFERENCES}

Agatz, N., Erera, A., Savelsbergh, M. \& Wang, X. (2012). Optimization for dynamic ride-sharing: A review. European Journal of Operational Research, 223, 295-303. https://doi.org/10.1016/j.ejor.2012.05.028

Aguilera-Garcia, A., Gomez, J. \& Sobrino, N. (2020). Exploring the adoption of moped scooter-sharing systems in Spanish urban areas. Cities, 96, 1-13. https://doi.org/10.1016/j.cities.2019.102424

Akyelken, N., Banister, D. \& Givoni, M. (2018). The Sustainability of Shared Mobility in London: The Dilemma for Governance. Sustainability, 10(2), 1-13. https:// doi.org/10.3390/su10020420

Albinsson, P. A. \& Perera, B. Y. (2018). The Rise of the Sharing Economy: Exploring the Challenges and Opportunities of Collaborative Consumption. (1st. ed.) California: Praeger.

Allem, J. P. \& Majmundar, A. (2019). Are electric scooters promoted on social media with safety in mind? A case study on Bird's Instagram. Preventive Medicine Reports, 13, 62-63. https://doi.org/10.1016/j.pmedr.2018.11.013

Altinay, L. \& Taheri, B. (2018). Emerging themes and theories in the sharing economy: a critical note for hospitality and tourism. International Journal of Contemporary Hospitality Management, 31(1), 180-193. https://doi.org/10.1108/IJCHM-02-2018-0171

Bai, S. \& Jiao, J. (2020). Dockless E-scooter usage patterns and urban built Environments: A comparison study of Austin, TX, and Minneapolis, MN. Travel Behaviour and Society, 20, $264-272$. https://doi.org/10.1016/j.tbs.2020.04.005

Balac, M., Ciari, F. \& Axhausen, K. W. (2017). Modeling the impact of parking price policy on freefloating car-sharing: Case study for Zurich, Switzerland. Transportation Research Part C, 77, 207-225. https://doi.org/10.1016/j.trc.2017.01.022

Ballus-Armet, I., Shaheen, S. A., Clonts, K. \& Weinzimmer, D. (2014). Peer-to-Peer Carsharing Exploring Public Perception and Market Characteristics in the San Francisco Bay Area, California. Transportation Research Record: Journal of the Transportation Research Board, 2416, 27-36. https://doi.org/10.3141/2416$\underline{04}$

Bardhi, F. \& Eckhardt, G. M. (2012). Access-Based Consumption: The Case of car-sharing. Journal of Consumer Research, 39(4), 881-898. https://doi.org/10.1086/666376

Belk, R. (2007). Why Not Share Rather Than Own?. AAPSS, 611, 126-140. https://doi.org/10.1177/0002716206298483

Belk, R. (2010). Sharing. Journal of Consumer Research. 36(5), 715-734. https://doi.org/10.1086/612649

Belk, R. (2014). You are what you can access: Sharing and collaborative consumption online. Journal of Business Research, 67(8), 1595-1600. https:// doi.org/10.1016/j.jbusres.2013.10.001

Botsman, R. \& Rogers, R. (2010). What's Mine Is Yours: The Rise of Collaborative Consumption (1st ed.). New York: Harper Collins. https://doi.org/10.5860/choice.48-3364

Buczynski, B. (2013). Sharing is good: how to save money, time and resources through collaborative consumption. (1st ed.). Canada: New Society Publishers.

Campbell, A. A., Cherry, C. R., Ryerson, M. R. \& Yang, X. (2016). Factors influencing the choice of shared bicycles and shared electric bikes in Beijing. Transportation Research Part C, 67, $399-414$. https://doi.org/10.1016/j.trc.2016.03.004

Ciari, F., Bock, B. \& Balmer, M. (2014). Modeling Station-Based and Free-Floating Car-sharing Demand: Test Case Study for Berlin. Transportation Research Record: Journal of the Transportation Research Board, 2416(1), 37-47. https:// doi.org/10.3141/2416-05

Ciari, F. \& Becker, H. (2017). How Disruptive Can Shared Mobility Be? A Scenario-Based Evaluation of Shared Mobility Systems Implemented at Large Scale. In Disrupting Mobility: Impacts of Sharing Economy and Innovative Transportation on Cities. eds. Meyer, G. \& Shaheen, S. Switzerland: Springer: 51-63. https://doi.org/10.1007/978-3-319-51602-8_3 
Chen, Y. \& Wang, L. (2019). Commentary: Marketing and the Sharing Economy: Digital Economy and Emerging Market Challenges. Journal of Marketing, 83(5), 28-31. https://doi.org/10.1177/0022242919868470

Choi, H. R., Min Je Cho, Lee, K., Hong, S. G. \& Woo, C. R. (2014). The Business Model for the Sharing Economy between SMEs. WSEAS TRANSACTIONS on BUSINESS and ECONOMICS, 11, 625-634. https://doi.org/10.9723/jksiis.2016.21.5.041

Cohen, B. \& Kietzmann, J. (2014). Ride On! Mobility Business Models for the Sharing Economy. Organization \& Environment, 27(3), 279-296. https://doi.org/10.1177/1086026614546199

Cramer, J. \& Krueger, A. B. (2016). Disruptive Change in the Taxi Business: The Case of Uber. American Economic Review, 106(5), 1-14. https://doi.org/10.1257/aer.p20161002

Deloitte. (2017). What's ahead for fully autonomous driving Consumer opinions on advanced vehicle technology. Retrieved from https://www2.deloitte.com/content/dam/Deloitte/us/Documents/manufacturing/usmanufacturing-consumer-opinions-on-advanced-vehicle-technology.pdf. (Last accessed: 06 June 2020).

Eckhardt, G. M., Houston, M. B., Jiang, B. Lamberton, C., Rindfleischand, A. \& Zervas, G. (2009). Marketing in a Sharing Economy. Journal of Marketing, 83(5), 5-27. https://doi.org/10.1177/0022242919861929

Feigon, S. \& Murphy, C. (2016). Shared Mobility and the Transformation of Public Transit. (1st ed.). Chicago: THE NATIONAL ACADEMIES PRESS. https:// doi.org/10.17226/23578

Firnkorn, J. \& Müller, M. (2011). What will be the environmental effects of new free-floating car-sharing systems? The case of car2go in Ulm. Ecological Economics, 70, 1519-1528. https://doi.org/10.1016/j.ecolecon.2011.03.014

Firnkorn, J. \& Müller, M. (2015). Free-floating electric carsharing-fleets in smart cities: The dawning of a post-private car era in urban environments?. Environmental Science and Policy, 45, 30-40. https://doi.org/10.1016/j.envsci.2014.09.005

Fishman, E., Washington, S. \& Haworth, N. (2013). Bike Share: A Synthesis of the Literature. Transport Reviews, 33(2), 148-165. https://doi.org/10.1080/01441647.2013.775612

Hamari, J., Sjöklint, M. \& Ukkonen, A. (2015). The Sharing Economy: Why People Participate in Collaborative Consumption. Journal of The Association For Information Science And Technology, 67(9), 20472059. https://doi.org/10.1002/asi.23552

Hampshire, R. C. \& Gaites, C. (2011). Peer-to-Peer Carsharing: Market Analysis and Potential Growth. Transportation Research Record: Journal of the Transportation Research Board, 2217, 119-126. https://doi.org/10.3141/2217-15

Hardt, C. \& Bogenberger, K. (2019). Usage of e-Scooters in Urban Environments. Transportation Research Procedia, 37, 155-162. https://doi.org/10.1016/j.trpro.2018.12.178

Hartl, B., Sabitzer, T., Hofmann, E. \& Penz, E. (2018). "Sustainability is a nice bonus" the role of sustainability in car-sharing from a consumer perspective. Journal of Cleaner Production, 202, 88-100. https://doi.org/10.1016/i.jclepro.2018.08.138

Henao, A. \& Marshall, W. (2017). A Framework for Understanding the Impacts of Ridesourcing on Transportation. In Disrupting Mobility: Impacts of Sharing Economy and Innovative Transportation on Cities. eds. Meyer, G. \& Shaheen, S. Switzerland: Springer, 197-209. https://doi.org/10.1007/978-3-31951602-8_13

Iacobucci, J., Hovenkotter, K. \& Anbinder, J. (2017). Transit Systems and the Impacts of Shared Mobility. In Disrupting Mobility: Impacts of Sharing Economy and Innovative Transportation on Cities. eds. Meyer, G. \& Shaheen, S. Switzerland: Springer, 65-76. https://doi.org/10.1007/978-3-319-51602-8_4

ING. (2020). ING Paylaşım Ekonomisi Uluslararası Basın Bülteni. Retrieved from https:// www.ing.com.tr/F/Documents/pdf/Basin_Odasi/2015/ingbank_IIS_paylasim_ekonomisi_2 1122015.pdf. (Last accessed: 06 June 2020). 
Jin, Scarlett T., Hui Kong, Rachel Wu, Daniel Z. Sui. (2018). Ridesourcing, the sharing economy, and the future of cities. Cities, 76, 96-104. https://doi.org/10.1016/j.cities.2018.01.012

Jochem, P., Frankenhauser, D., Ewald, L. \& Ensslen, A. 2020. Does free-floating car-sharing reduce private vehicle ownership? The case of SHARE NOW in European cities. Transportation Research Part A, 141, 373-395. https://doi.org/10.1016/j.tra.2020.09.016

Jorge, D., Barnhart, C. \& Correia, G. H. d. A. (2015). Assessing the viability of enabling a round-trip carsharing system to accept one-way trips: Application to Logan Airport in Boston. Transportation Research Part C, 56, 359-372. https://doi.org/10.1016/j.trc.2015.04.020

Katzev, R. (2003). car-sharing: A New Approach to Urban Transportation Problems. Analyses of Social Issues and Public Policy, 3(1), 65-86. https://doi.org/10.1111/j.1530-2415.2003.00015.x

Kim, Y. G., Woo, E. \& Nam, J. (2018). Sharing economy perspective on an integrative framework of the NAM and TPB. International Journal of Hospitality Management, 72, 109-117. https://doi.org/10.1016/j.ijhm.2018.01.008

Kim, D., Park, Y. \& Ko, J. (2019). Factors underlying vehicle ownership reduction among car-sharing users: A repeated cross-sectional analysis. Transportation Research Part D, 76, 123-137. https://doi.org/10.1016/j.trd.2019.09.018

Klincevicius, M. G. Y., Morency, C. \& Trépanier, M. (2014). Assessing Impact of Carsharing on Household Car Ownership in Montreal, Quebec, Canada. Transportation Research Record: Journal of the Transportation Research Board, 2416(1), 48-55. https://doi.org/10.3141/2416-06

Kopp, J., Gerike, R. \& Axhauen, K. W. (2015). Do sharing people behave differently? An empirical evaluation of the distinctive mobility patterns of free-floating car-sharing members. Transportation, 42, 449-469. https:// doi.org/10.1007/s11116-015-9606-1

Le Vine, S., Lee-Gosselin, M., Sivakumar, A. \& Polak, J. (2014). A new approach to predict the market and impacts of round-trip and point-to-point car-sharing systems: Case study of London. Transportation Research Part D, 32, 218-229. https://doi.org/10.1016/j.trd.2014.07.005

Liu, Y. \& Yang, Y. (2018). Empirical Examination of Users' Adoption of the Sharing Economy in China Using an Expanded Technology Acceptance Model. Sustainability, 10(1262), 1-17. https://doi.org/10.3390/su10041262

Mao, Z. \& Lyu, J. (2017). Why travelers use Airbnb again? An integrative approach to understanding travelers' repurchase intention. International Journal of Contemporary Hospitality Management, 29(9), 24642482. https://doi.org/10.1108/IJCHM-08-2016-0439

McKenzie, G. (2019). Spatiotemporal comparative analysis of scooter-share and bike-share usage patterns in Washington, D.C.. Journal of Transport Geography, 78, 19-28. https://doi.org/10.1016/j.jtrangeo.2019.05.007

McKenzie, G. (2020). Urban mobility in the sharing economy: A spatiotemporal comparison of shared mobility services. Computers, Environment and Urban Systems, 79, 1-10. https://doi.org/10.1016/j.compenvurbsys.2019.101418

Millard-Ball, A., Murray, G., Schure, J. T., Fox, C. \& Burkhardt, J. 2005. Car-Sharing: Where and How It Succeeds. Transportation Research Board, 108, 1-246. https://doi.org/10.17226/13559

Münzel, K., Piscicelli, L., Boon, W. \& Frenken, K. (2019). Different business models - different users? Uncovering the motives and characteristics of business-to-consumer and peer-to-peer car-sharing adopters in The Netherlands. Transportation Research Part D, 73, 276-306. https://doi.org/10.1016/j.trd.2019.07.001

Nwaorgu, B. (2018). What is Collaborative Consumption? Platforms and Participation of People in Collaborative Consumption - Impact of the New Technologies. International Journal of Innovation and Technology Management, 9(6), 240-245. https://doi.org/10.18178/ijimt.2018.9.6.819 
Pappas, N. (2016). The complexity of purchasing intentions in peer-to-peer accommodation. International Journal of Contemporary Hospitality Management, 29(9), 2302-2321. https://doi.org/10.1108/IJCHM-08-2016-0429

Paundra, J., Rook, L. van Dalen, J. \& Ketter, W. (2017). Preferences for car-sharing services: Effects of instrumental attributes and psychological ownership. Journal of Environmental Psychology, 53, 121-130. https://doi.org/10.1016/j.jenvp.2017.07.003

Posen, H. A. (2016). Ridesharing in the Sharing Economy: Should Regulators Impose Über Regulations on Uber?. Iowa Law Review, 101(1), 405-433.

PWC. (2015a). Sharing or pairing? Growth of the sharing economy. Retrieved from https://www.pwc.com/hu/en/kiadvanyok/assets/pdf/sharing-economy-en.pdf. (Last accessed: 04 June 2020).

PWC. (2015b). The Sharing Economy: Consumer Intelligence Series. Retrieved from https:// www.pwc.fr/fr/assets/files/pdf/2015/05/pwc_etude_sharing_economy.pdf. (Last accessed: 04 June 2020).

PWC. (2017). Share economy 2017: The New Business Model. Retrieved from https://www.pwc.at/de/publikationen/branchen-und-wirtschaftsstudien/share-economy-report-

2017.pdf. (Last accessed: 06 June 2020).

Ranjbari, M., Gustavo, M. A. \& Carrasco-Gallego, R. (2018). Conceptualizing the Sharing Economy through Presenting a Comprehensive Framework. Sustainability, 10(2336), 1-24. https://doi.org/10.3390/su10072336

Schechtner, K. \& Hanson, M. (2017). Shared Mobility in Asian Megacities: The Rise of the Apps. In Disrupting Mobility: Impacts of Sharing Economy and Innovative Transportation on Cities. eds. Meyer, G. \& Shaheen, S. Switzerland: Springer, 77-88. https://doi.org/10.1007/978-3-319-51602-8_5

Schneider, H. (2017). Creative Destruction and the Sharing Economy. Creative Destruction and the Sharing Economy. (1st ed.) Cheltenham: Edward Elgar Publishing Limited.

Schroders. (2020). The Sharing Economy. Retrieved from https://www.schroders.com/nl/sysglobalassets/digital/resources/pdfs/2016-08-the-sharingeconomy.pdf. (Last accessed: 03 June 2020).

Shaheen, S., Chan, N., Bansal, A. \& Cohen, A. (2015), Shared Mobility: A Sustainability and Technologies Workshop: Definitions, Industry developments, and Early Understanding. UC Berkeley Transportation Sustainability Research Center, 1-31.

Shaheen, S., Cohen, A. \& Zohdy, I. (2016). Shared Mobility: Current Practices and Guiding Principles. UC Berkeley Transportation Sustainability Research Center, 1-120.

Shaheen, S. A., Bansal, A., Chan, N. \& Cohen, A. (2017a). Mobility and the Sharing Economy: Industry Developments and Early Understanding of Impacts. UC Berkeley Transportation Sustainability Research Center, 1-15. https://doi.org/10.1049/PBTR006E_CH10

Shaheen, S., Stocker, A. \& Mundler, M. (2017b). Online and App-Based Carpooling in France: Analyzing Users and Practices-A Study of BlaBlaCar. In Disrupting Mobility: Impacts of Sharing Economy and Innovative Transportation on Cities. eds. Meyer, G. \& Shaheen, S. Switzerland: Springer, 181-196. https://doi.org/10.1007/978-3-319-51602-8_12

Shaheen, S. \& Cohen, A. (2019). Shared Micromoblity Policy Toolkit: Docked and Dockless Bike and Scooter Sharing. UC Berkeley Transportation Sustainability Research Center, 1-31. https://doi.org/10.7922/G2TH8JW7

Statista. (2020). Number of sharing economy users in the United States from 2016 to 2021. Retrieved from https://www.statista.com/statistics/649459/carsharing-fleet-worldwide/. (Last accessed: 04 June 2020). 
Tong, Y., Zeng, Y., Zhou, Z., Chen, L., Ye, J. \& Xu, K. (2018). A unified approach to route planning for shared mobility. Proceedings of the VLDB Endowment, 11, 1633-1646. https://doi.org/10.14778/3236187.3236211

Tussyadiah, I. P. \& Zach, F. (2017). Identifying salient attributes of peer-to-peer accommodation experience. Journal of Travel \& Tourism Marketing, 34(5), 636-652. https://doi.org/10.1080/10548408.2016.1209153

Wang, M. \& Zhou, X. (2017). Bike-sharing systems and congestion: Evidence from US cities. Journal of Transport Geography, 65, 147-154. https://doi.org/10.1016/i.jtrangeo.2017.10.022

Webrazzi. [2020]. MOOOV by Garenta Paylaşımlı Araç Büyüme Verileri. Retrieved from https:// webrazzi.com/2020/06/09/moov-by-garenta-gectigimiz-hafta-yuzde-93-luk-artisla-30binden-fazla-kiralamaya-imza-atti/. (Last accessed: 02 July 2020).

Wielinski, G., Trepanier, M. \& Morency, C. (2017). Carsharing Versus Bikesharing: Comparing Mobility Behaviors. Transportation Research Record: Journal of the Transportation Research Board, 2650(1), 112-122. https://doi.org/10.3141/2650-13

Wilhelms, M. P., Henkel, S. \& Falk, T. (2017a). To earn is not enough: A means-end analysis to uncover peer-providers' participation motives in peer-to-peer car-sharing. Technological Forecasting and Social Change, 125, 38-47. https:// doi.org/10.1016/j.techfore.2017.03.030

Wilhelms, M. P., Henkel, S. \& Merfeld, K. (2017b). You Are What You Share: Understanding Participation Motives in Peer-to-Peer Carsharing. In Disrupting Mobility: Impacts of Sharing Economy and Innovative Transportation on Cities. eds. Meyer, G. \& Shaheen, S. Switzerland: Springer: 105-119. https://doi.org/10.1007/978-3-319-51602-8_7

Yau, A. \& Mahn, A. (2015). Sharing Is Dubious, It Won'T Work! Exploring the Barriers Towards Collaborative Consumption of Free Floating car-sharing. Advances in Consumer Research Volume, 43, 746747.

Yoon, T., Cherry, C. R. \& Jones, L. R. (2017). One-way and round-trip car-sharing: A stated preference experiment in Beijing. Transportation Research Part D, 53, 102-114. https://doi.org/10.1016/j.trd.2017.04.009

Yun, J. H. J., Zhao, X., Wu, J., Yi, J. C., Park, K. B. \& Jung, W. Y. (2020). Business Model, Open Innovation, and Sustainability in car-sharing Industry - Comparing Three Economies. Sustainability, 12(1883): 1-27. https://doi.org/10.3390/su12051883

Zhu, G., So, K. K. F. \& Hudson, S. (2017). Inside the sharing economy: Understanding consumer motivations behind the adoption of mobile applications. International Journal of Contemporary Hospitality Management, 29(9), 2218-2239. https://doi.org/10.1108/IJCHM-09-2016-0496 